\title{
Impact of the Economic Stimulus Measures on Lithuanian Real Estate Market under the Conditions of the COVID-19 Pandemic
}

\author{
Vaida Pilinkiene, Alina Stundziene, Evaldas Stankevicius, Andrius Grybauskas
}

\author{
Kaunas University of Technology \\ K. Donelaicio st. 73, LT-44029, Kaunas, Lithuania \\ E-mail.vaida.pilinkiene@ktu.lt; alina.stundziene@ktu.lt; evaldas.stankevicius@ktu.lt; andrius.grybauskas@ktu.lt \\ cross $^{\text {ref }}$ http://dx.doi.org/10.5755/j01.ee.32.5.28057
}

The COVID-19 pandemic caused a number of challenges worldwide regarding not only the human health perspective, but also the economic situation. Quarantine, imposed in many countries, forced a substantial part of businesses to close or narrow down their activities, thus leaving corporations and employees without any or with lower income. If national governments had not undertaken any actions to save national economies, the consequences could have been even more devastating. The real estate market is an important part of economy. Instability in the real estate market can cause financial problems, vulnerability of population's welfare and other negative effects. This research aims to assess the impact of the economic stimulus measures on the real estate market under the conditions of the COVID-19 pandemic in Lithuania. The research methods include comparative analysis, correlation analysis, stationarity test, regression analysis and the ARDL models. The results indicate that the economic stimulus measures only partially contribute to stabilization of the real estate market in Lithuania. The drop in housing prices was 2.9 percent lower because of the economic stimulus in the second quarter of 2020. Maintenance of household cash and deposits as well as lending to business enterprises are the measures that allow to stabilize the real estate market in the shortest time under the conditions of the economic shock. The other governmental support measures are also important, especially if they are aimed at preserving jobs.

Keywords: Economic Stimulus, Real Estate; COVID-19; Housing Price; Economic Shock.

\section{Introduction}

The real estate (RE) market is closely related to the national economy and its sectors, and fluctuations in the real estate market affect the long-term national economic development and viability. The RE market stability is affected not only by national economic policies and expectations of market participants, but also by some external factors, such as economic shocks that are described as a sudden change in operating conditions in the economic, political, social or natural environment. In the absence of an adequate governmental response to an economic shock, a sudden, and often negative, impact on the economy and its sectors is plausible.

The economic crisis of 2008-2009 revealed that the RE sector is directly linked to the economic and social welfare of households, bank liquidity and the ability of corporations to meet their financial obligations. Uncontrolled fluctuations in real estate prices caused the destabilising effects in the RE market, which later led to the negative adjustments in macroeconomic and competitiveness indicators, tightening of fiscal and monetary policy measures, and social tensions in the society. The economic shock of 2020 , caused by the COVID-19 pandemic, forced a part of the corporations in the country to close or narrow down their activities, led to an increase in the unemployment rate, reduced population's income, aggregate demand, and had a negative impact on loan holders in terms of meeting their financial obligations.

The economic and social effects of the COVID-19 pandemic are closely linked to the national real estate market. If the effects of this economic shock are not remedied in due time and government-initiated stimulus measures fail to reach target economic entities, RE prices may fall below the asset value and lead to households voluntarily waiving their financial obligations, thus raising the likelihood of bankruptcy of natural persons and violating the sustainable social dimension. In this case, banks would be forced to accept illiquid assets as a form of loss, and the economic upheaval would have dire social consequences, e.g. loss of housing. In addition to these scenarios, a number of other RE market participants would find themselves in a difficult situation: possession of dwindling financial resources would make it risky for RE developers and managers to run and complete new projects, while commercial banks would tighten lending conditions. It is obvious that such an economic shock may lead to difficult-to-manage consequences for the RE market participants, and may also directly affect fiscal stability of the economy as well as development of responsible social policies.

The sudden global economic shock caused by the COVID19 pandemic confirms the important role of a state as a promoter of the economy. Since the beginning of the pandemic, national governments have integrated monetary and fiscal policy instruments into the economic stimulus measures, i.e. loan deferrals, interest rate compensation mechanisms, payments to households, wage and downtime compensations, etc. In the first two months of the pandemic in 2020, national governments announced about the intentions to allocate $\$ 10$ trillion, i.e. 3 times as much as the value of the measures employed to stimulate the global economy during the crisis of 2008-2009 (Cassim et al., 2020). 
In response to the crisis, in March 2020 the Lithuanian government also launched the "COVID-19 Response Economic and Financial Action Plan" which focuses on stimulating the economy negatively affected by the coronavirus pandemic. Nevertheless, the economic stimulus measures approved by the Lithuanian government are only partially aimed at stabilising the RE market. It is uncertain whether the measures approved will contribute to addressing the negative effects of the COVID-19 pandemic in a timely manner, whether the fluctuations in both the national economy and the RE market will be stabilised, and whether the market participants targeted by the stimulus measures will remain economically and socially secure. Thus, the main aim of this research is to assess the impact of the economic stimulus measures on the real estate market under the conditions of the COVID-19 pandemic in Lithuania.

A study by Cassim et al. (2020) on the stimulus measures in 54 countries worldwide revealed quite different national responses to the pandemic-caused economic shock. The research indicates that the volume of the economic stimulus measures relative to GDP ranged from a few (e.g. $5.5 \%$ in Brazil) to several tens of percent (e.g. $33 \%$ in Germany) in different countries, and depended on the extent of the pandemic outbreak as well as existing social and business support measures, industrial structure, etc. There is also no unequivocal answer as to what measures countries should undertake to deal with the effects of the COVID-19 pandemic. Each country should make the decisions based on the structure of its economy. In the case of Lithuania, the research assessing the effectiveness of the economic stimulus measures, approved by the Lithuanian government, from the position of the RE market is completely new. In general, since the problem of the COVID-19 pandemic is new, most previous studies mainly focus on investigating the negative effects of the pandemic on the financial market (Zhang et al., 2020; Mazur et al., 2020; Akhtaruzzaman et al., 2020; Mirza et al., 2020; Shehzad et al., 2020; Leduc et al., 2020; Sharif et al., 2020; Choi, 2020) or industries (Belhadia et al., 2020; Goodell et al., 2020; Hossain, 2020) rather than the real estate market.

This research is based on the methods of comparative analysis, correlation analysis, stationarity test, regression analysis and the ARDL models. The research starts with the literature analysis concerning the role of national governments in the event of an economic shock. The data and methods are described in the Methodology section. Finally, the results and conclusions are delivered.

\section{Literature Analysis}

When analysing scientific literature, it is difficult to single out a unified description of an economic shock since shocks affect a number of areas and range in their impact intensity, time and environmental factors. An economic shock is commonly referred to as a sudden change in macroeconomic conditions manifesting through fluctuating exchange rates, inflation, interest rates, restrictions placed upon economic activities, imposition of trade barriers, and so forth. Economic shocks are also associated with fluctuations in economic growth and structural stagnation of the industries linked to hampered economic development (Karpavicius, 2012). In a general sense, an economic shock is defined as a sudden change in operating conditions in the economic, political, social or natural environment. In the absence of an adequate governmental response to an economic shock, a sudden and often negative impact on national economic development is plausible (Bruneckiene et al., 2019). In the event of an economic shock, a quick reaction to the changes as well as making appropriate decisions to stabilize the economy are essential.

Economic shocks are characterised not only by the transition from one sector of the economy to another, but also by their easy transmission to the economies of other countries. In general, the role of a state in stabilising a national economy is stimulative and involves governmental actions aimed at stimulating economic activities in the private sector through targeted monetary and/or fiscal policies invoked to compensate for aggregate demand disbalances. Monetary stimulus means the actions of the national central bank undertaken to control money supply and interest rate, e.g. interest rate cuts which affect demand for loans and consumption decisions. Fiscal stimulus means fiscal policy measures aimed at reducing tax liabilities or increasing government spending in order to stimulate economic activities and investment. Such measures include temporary tax reductions or deferrals, reimbursement of particular private sector costs, extra payments to households, etc. Combinations of both policies enable a more efficient use of resources, stimulate consumption and restore economic imbalances caused by an economic shock.

The impact of most economic stimulus measures is complex, and implementation of these measures has a direct impact on aggregate demand and thus on the demand for RE. Under the conditions of an economic shock, RE prices fluctuate, which later causes national economic instability and insolvency of market participants. State aid aimed at ensuring the stability of the RE market would also allow stabilising the national economy in the long-run. According to Paavonen (2010), urgent economic stabilization programs, undertaken by national governments to counteract an economic shock, are mostly based on a money supply mechanism activated to help financial institutions to prevent bankruptcies by redeeming bad loans, making additional capital injections or reinsuring loans, which improves business liquidity and solvency, and prevents financial and RE market downturns.

Bloch (1997) notes that the RE market cycles can be managed and controlled by public authorities; therefore, a state's intervention into the RE market is an effective way to prevent RE price fluctuations. RE prices, which are unrelated to fundamental macroeconomic indicators, tend to cause problems of economic and social instability. Previous studies reveal that stabilisation of the RE market is positively affected by a favourable macroeconomic and tax environment, which, in its turn, is directly influenced by the measures implemented by public authorities. Among such measures, Anghel and Hristea (2015) mention the RE tax, governmental support for RE acquisition, VAT and interest rates. Amedee-Manesme et al.'s (2016) empirical research in the U.S. market indicates that the attractiveness of the RE market, and at the same time the lower risk of RE crises, is determined by a controlled exchange rate, purchase-sale transaction costs and taxes. According to Lu and Dong (2016), fluctuations in Chinese residential RE market prices are affected by governmental 
decisions related to rational urban development, and fiscal and monetary measures, i.e. loan interest rate, exchange rate stability, inflation, FDI level. Haas and Greef (2000) state that stability of the Dutch residential RE market is determined by both the general macroeconomic environment and the interest rate, loan volume, etc.

Most authors agree that the macroeconomic policy pursued by a state must be cyclical, i.e. it should not stimulate developer and consumer expectations during the period of an upswing, but should protect against a forced sale of RE during the period of an economic crisis or shock. Johnson and Neave's (2008) research indicates that although a state's participation in the RE market manifests through regulation of the taxation system, infrastructure, income level and migration policies, an effective risky loan control mechanism is still lacking. According to Cocconcelli and Medda (2013), a properly differentiated RE tax system not only supplements a state's budget, but also acts as a stabiliser against an economic shock. The diversity of a state's support when stabilising the RE market is also emphasised by Azbainis (2013). In his opinion, a systemic and sectoral approach is required, i.e. the RE market control should be adjusted to the constantly changing macro-environment, economic stimulus programs should be focused on particular RE sectors, and RE market stabilisation measures should be developed considering specificities of each sector.

The necessity of a state-conducted systemic regulation of both the RE market and the entire financial sector was highlighted by the 2008-2009 crisis. Although, according to the general equilibrium theory, the free market itself is capable of allocating resources and distributing risks, and regulation of the $\mathrm{RE}$ market requires only monitoring particular financial institutions, the collapse of the RE markets worldwide revealed an obvious financial instability and economic imbalances. In response to the abovementioned challenges, the EU member states began to develop and implement macropudential policies. These are policies aimed at contributing to stability of the financial system, including strengthening its resilience and reducing systemic risks, so that a sustainable contribution of the financial system to further economic growth would be ensured (the Bank of Lithuania, 2020a). One of the main macroprudential policy indicators that helps to assess the supply and demand situation in the credit market, evaluate the risks assumed by market participants and the risks of the RE market overheating is loan-to-value ratio (hereinafter, LTV). From a macroprudential point of view, the maximum allowable LTV indicator or the minimum collateral value requirement could help to diminish bank losses incurred due to default by the debtor and reduce a default probability (Matkenaite et al., 2016). However, the macroprudential objective is much more important in terms of stabilising the RE market because it is linked to a positive impact on the stability of the banking system, sustainable lending and balanced economic growth.

The restrictive effect of the LTV indicator on the RE market participants is multifaceted, i.e. it can be treated as a requirement for improved collateral coverage, a requirement for a higher down payment or a limitation placed upon a debtor's financial leverage. The impact of LTV tightening on the RE market depends on market conditions and the behaviour of market participants. Under the conditions of an economic shock, the LTV indicator tightening may cause a strong short-term impact on the RE market demand, diminish the incentives for speculation and prevent the RE price bubble formation.

The empirical studies confirm the potential to reduce the excessive activity and cyclicality of the RE market by placing stricter limitations upon the LTV indicator. McDonald (2015) reviewed 100 LTV indicator adjustment cases in 17 countries and found that changing the LTV indicator thresholds has a greater impact when the credit market is expanding rapidly and the level of residential RE prices is rising. After tightening the LTV indicator during the period of economic growth, the volumes of the housing loan market shrank by 4-8 percent, and the level of housing prices fell by 6-12 percent. Conversely, during the period of an economic downturn, the volumes of the housing loan market fell by 2-3 percent, and the level of housing prices dropped by 2-4 percent. In other words, the effect of the LTV indicator tightening is greater when credit volumes and RE prices are rising rapidly, but the effect is small when both credit volumes and RE prices are falling. Zhang and Zoli (2014) researched application of macroprudential policy instruments and capital flows in 46 countries and confirmed that these instruments helped curb a housing price increase, property flows and credit market growth.

Shim and Shin's (2014) research of 12 Asia-Pacific countries also indicated that macroprudential instruments are linked to the capital flow and RE management policies, and revealed that macroprudential instruments are more effective when they complement monetary policies during the periods of an economic downturn or shock.

The role of a state in stabilising the RE market is also confirmed by the 'Financial Instability Hypothesis' developed by H. P. Minsky; based on this hypothesis, namely banking and lending activities underlie financial instability, making an economy structurally fragile. According to Minsky (1992), a financial crisis following the periods of economic growth is bound to prompt lenders and borrowers to be reckless and assume a much higher risk than that assumed under regular conditions. Businesses are taking out ever-increasing loans, thus allocating rising shares of their future revenue for loan repayment. If a country does not have any responsible borrowing policies and its financial supervision institutions act ineffectively, the risk of insolvency of economic agents can be mazimised. In fact, any external economic shock can exacerbate the situation, and the excessive optimism ends in the collapse of the financial and RE markets.

Literature addresses various regional resilience factors that allow to control a shock-affected economy. Resilience is the term used in many areas of science and widely applied in economic research. In terms of reacting to an economic shock, resilience is defined as the ability to anticipate, take preventive actions, respond to shakes and adapt to them. Resilience aims at the ability to react and recover from external shocks so that economic growth would be ensured (Palekiene et al., 2015).

The response to economic shocks varies from country to country. According to Carrière-Swallow and Cespedes (2013), recovery after a crisis takes much longer for developing countries: they lose a significant part of investment (investment falls fourfold compared to developed countries) and face the challenges of declining consumption 
and high unemployment rate. Economic shocks along with the ensuing economic downturn negatively affect financial institutions: the volumes of loans are declining and credits are granted only after a detailed assessment of a customer's ability to repay them.

When stabilising the economic situation, base interest rates can be employed, although this instrument not always leads to an expected result. Sidlauskaite-Riazanova and Seputiene's (2008) study indicates that over the period before the economic crisis of 2009, the interest rate set by the Euporean Central Bank was less favourable in the member states characterised by faster economic growth.

The instruments that would allow states to solve their problems in the RE market under the conditions of the COVID-19 pandemic may vary, and there are still no firm conclusions concerning the effectiveness of these instruments. The Turkish government adopted the regulations aimed at fixing low-interest rates and issuing long-term housing loans from public banks; they also carried out land registry transactions online, reduced land registry fees, took steps to prevent financial bankruptcies, started implementing flexible working hours, and prohibited layoffs. However, according to Tanrivermis (2020), the efforts to revive the RE markets by increasing the sales of existing residences and businesses and employing tourism-oriented measures are inadequate. Allam (2020) notes that most developed and some developing economies with balanced payments in respect to their GDP propose robust economic and social stimulus packages to cushion their economies and the population from the negative impacts of the pandemic. Meanwhile, least developed economies still rely on external financial aid.

It is also important to assess the evolution of previous economic shocks and their effects so that appropriate stabilisation strategies can be developed and preparation for potential shocks can be started in the stage of an economic upswing. Since economic shocks related to extreme situations (e.g. natural disasters, pandemics) lead to difficult conditions, it is essential to be prepared to respond appropriately to potential threats and to develop strategic plans to deal with the effects of these shocks. The characteristics of the economic shock caused by the COVID-19 pandemic, in comparison to the shock caused by the global financial crisis of 2008, were discussed by Shehzad et al. (2020), Laing (2020), Yarovaya et al. (2020), etc.

\section{Methodology and Data}

This research covers the analysis of the "COVID-19 Response Economic and Financial Action Plan" launched by the Lithuanian government and the relationship of this plan with fluctuations in macroeconomic indicators. In the first stage of the research, macroeconomic indicators that reflect the extent of the economic stimulus were identified. The selection of the indicators was performed based on two requirements:

- they had to be described by sufficiently long time series (preferred from 2000);

- they had to possess quarterly data in order to measure their changes during the pandemic.

The selection of indicators that reflect the extent of the economic stimulus best is reasoned in the description of the results (next section). The data of selected variables was collected from 2000Q1-2020Q2, but several variables had shorter time series (from 2004 or 2005). The data was extracted from Official Statistics Portal (Statistics Lithuania, 2020) and the Bank of Lithuania (2020b).

This research is limited to housing price analysis as a measure of the real estate market. The average residential housing sale (transaction) price (euro per 1 sq. m) is chosen as the dependent variable in this research. It encompasses all existing dwelling in Lithuania (new and old construction houses and apartments). The data is obtained from 2000Q1 to 2020Q2 and is taken from State Enterprise Centre of Registers.

The impact of the economic stimulus on housing prices is assessed by applying the following methods:

- stationarity test;

- Granger causality test;

- correlation analysis;

- regression analysis;

- autoregressive distributed lag (ARDL) models.

Stationarity of time series $\left(y_{t}\right)$ is evaluated by applying unit root test. Testing covers the following models:

$$
\begin{aligned}
& \Delta y_{t}=\theta y_{t-1}+U_{t} \\
& \Delta y_{t}=\beta_{0}+\theta y_{t-1}+U_{t} \\
& \Delta y_{t}=\beta_{0}+\beta_{1} t+\theta y_{t-1}+U_{t}
\end{aligned}
$$

here $y_{t-1}$ denotes the value of time series at the moment $t-1$, $(t=1,2, \ldots, n) ; \Delta y_{t}$ stands for the difference between adjacent values of time series $\left(\Delta y_{t}=y_{t}-y_{t-1}\right) ; \beta_{0}, \beta_{1}$ and $\theta$ denote the parameters; $U_{t}$ marks the errors of the model.

The following hypotheses are tested:

$\mathrm{H}_{0}: \theta=0$, i.e. time series is not stationary;

$\mathrm{H}_{1}: \theta \neq 0$, i.e. time series is stationary.

The calculated probability $(p)$ is a measure that shows which hypothesis is accepted (in the latter case and all other cases described below). The significance level $(\alpha)$ of 0.05 is invoked. $\mathrm{H}_{0}$ is accepted if $p>\alpha$. If time series is not stationary, its values are differentiated. Stationarity of time series lets ensure reliable results of the further analysis and lets prevent a spurious regression.

Granger causality test is based on the analysis of the following models:

$$
\begin{aligned}
& y_{t}=\alpha_{0}+\alpha_{1} y_{t-1}+\cdots+\alpha_{i} y_{t-i}+\beta_{1} x_{t-1}+\cdots+ \\
& \beta_{i} x_{t-i}+U_{t} \\
& x_{t}=\alpha_{0}+\alpha_{1} x_{t-1}+\cdots+\alpha_{i} x_{t-i}+\beta_{1} y_{t-1}+\cdots+ \\
& \beta_{i} y_{t-i}+U_{t}
\end{aligned}
$$

here $x_{t}$ and $y_{t}$ denote time series values at the moment $t ; \alpha_{j}$, and $\beta_{j}$ mark the parameters, $j=0, \ldots, i$.

The following hypotheses are tested:

$$
\begin{aligned}
& \mathrm{H}_{0}: \beta_{1}=\beta_{2}=\cdots=\beta_{i}=0 ; \\
& \mathrm{H}_{1}: \text { at least one } \beta_{j} \neq 0, j=1, \ldots, i .
\end{aligned}
$$

$\mathrm{H}_{0}$ is accepted if $p>\alpha$. If $\mathrm{H}_{0}$ is accepted, it means that $x$ does not have any impact on the changes of $y$ in equation (4), and $y$ does not have any impact on the changes of $x$ in equation (5). If $\mathrm{H}_{0}$ is rejected, it means that $x$ is usefull for forecasting $y$ in equation (4), and $x$ Granger-causes $y$. 
The relationship between the two variables is measured by employing Pearson correlation coefficient:

$$
r_{x y}=\frac{\overline{x y}-\bar{x} \bar{y}}{s_{x} S_{y}}
$$

here $\bar{x}$ stands for the mean of $x$ values; $\bar{y}$ denotes the mean of $y$ values; $\overline{x y}$ marks the mean value of the product of $x$ and $y$; $S_{x}$ and $S_{y}$ are standard deviations of $x$ and $y$. Simple linear and non-linear regression models are analysed to detect the optimal relationship between each pair of $y$ and $x_{i}$.

Autoregressive distributed lag model (ARDL) lets evaluate the relationship between $y$ and $x_{i}$ by including lags of the dependent variable $(y)$ as well as independent variables $\left(x_{i}\right)$ :

$$
\begin{gathered}
y_{t}=\alpha_{0}+\alpha_{1} y_{t-1}+\cdots+\alpha_{i} y_{t-i}+\beta_{1} x_{1 t}+\cdots+ \\
\beta_{j} x_{1-j}+\gamma_{1} x_{2 t}+\cdots+\gamma_{j} x_{2 t-j}+\cdots+U_{t}
\end{gathered}
$$

The lag length is selected based on the significance of the parameters and the Akaike information criterion (AIC). Multicolinearity is also tested and eliminated from the model. Two independent variables $x_{i}$ and $x_{j}$ are collinear if Pearson correlation coefficient is equal or higher than 0.8. All the calculations are performed by using the EViews software.

\section{Research Results}

The "COVID-19 Response Economic and Financial Action Plan" launched by the Lithuanian government is aimed at:

1. providing the resources needed for the effective functioning of health and public protection systems, with a budget of EUR 500 million;

2. preserving jobs and population's income, with a budget of EUR 500 million;

3. preserving business liquidity, with a budget of EUR 500 million;

4. stimulating the economy, with a budget of EUR 1000 million;

5. ensuring the liquidity of the state's treasury, by granting the Government the right to borrow the additional EUR 5 billion.

The research revealed that the effects of the economic stimulus measures mainly manifest through the following macroeconomic indicators:

1. Since a major part of personal protective measures are purchased from China, the funds allocated for this purpose cannot have a significant impact of the financial situation of the state and its population. Because it is not possible to trace how much funds and for which purposes were transferred to the institutions involved in the extreme situation management, it is assumed that the funds allocated for the first of the above-mentioned aims affected only one macroeconomic indicator-government expenditure.

2. The funds allocated for the second aim are directed to increase the population's income. Unfortunately, the Official Statistics Portal provides only annual data on household income. Thus, this research employs some other indicators representing household income, i.e. total wages paid in the country (million EUR) (component of GDP estimated by applying the income method) and household cash and deposits. Interestingly, the data provided by the State Social
Insurance Fund Board (SODRA) indicate that the COVID-19 pandemic only temporarily affected population's income, and this effect was caused by the economic stimulus measures. In the second quarter of 2020, compared to the same period in 2019, population's average labour income subject to social insurance contributions increased by 5.3 percent to EUR 1,319 (before taxes), while in the first quarter of 2020, the annual growth was double-digit: it amounted to 10 percent; in the second quarter of 2020, compared to the first quarter, population's income decreased by 0.3 percent. Nevertheless, in June 2020, population's average monthly earnings subject to social insurance contributions increased by 11.4 percent compared to the same period in 2019 , i.e. the earnings increased by almost the same percentage as in January and February. The enterprises subsidized by the state did not record any substantial changes in the average labour income from February to June 2020, while the non-subsidized enterprises recorded a nearly 5 percent growth in the average labour income over the same period. Also, the funds allocated for this aim raised social benefits and government expenditure. Some measures also contributed to slower growth of the unemployment rate.

3. The funds allocated for the third aim may have affected the volume of loans to corporations, corporate liquidity ratio and the volume of subsidies.

4. It is assumed that the funds allocated for the fourth and fifth aims did not have any direct impact on the RE market related indicators.

The information on the extent of the economic stimulus measures and the macroeconomic indicators that reflect the extent of these measures is summarised in Table 1. Only the measures direcly linked to the macroeconomic indicators under consideration are included. 
Vaida Pilinkiene, Alina Stundziene, Evaldas Stankevicius, Andrius Grybauskas. Impact of the Economic Stimulus ...

Relationships between the Economic Stimulus Measures and Macroeconomic Indicators

Table 1

\begin{tabular}{|c|c|c|c|c|c|c|c|c|c|c|}
\hline \multirow[b]{2}{*}{ Measure } & \multicolumn{2}{|c|}{ Funds used } & \multicolumn{8}{|c|}{ Macroeconomic indicator } \\
\hline & Q2 & Q3 & 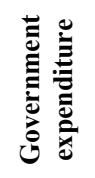 & 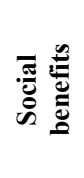 & 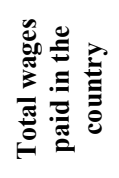 & 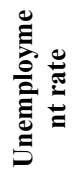 & ن & 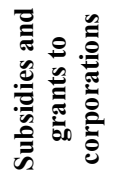 & 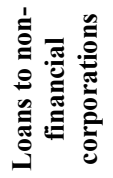 & 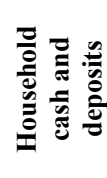 \\
\hline \multicolumn{11}{|l|}{ Aim 1: } \\
\hline $\begin{array}{l}\text { Funds for } \\
\text { personal } \\
\text { protective } \\
\text { measures and } \\
\text { Funds transferred } \\
\text { to the institutions } \\
\text { involved in the } \\
\text { extreme situation } \\
\text { management }\end{array}$ & $\begin{array}{l}\text { EUR } \\
63.63 \\
\text { million }\end{array}$ & $\begin{array}{c}\text { EUR } \\
18.15 \\
\text { million }\end{array}$ & $\mathrm{X}$ & & & & & & & \\
\hline \multicolumn{11}{|l|}{$\operatorname{Aim} 2:$} \\
\hline $\begin{array}{l}\text { 1. Support to } \\
\text { businesses to save } \\
\text { jobs and create } \\
\text { new ones }\end{array}$ & $\begin{array}{c}\text { EUR } \\
113.74 \\
\text { million / } \\
187982 \\
\text { persons }\end{array}$ & $\begin{array}{c}\text { EUR } \\
46.02 \\
\text { million / } \\
13457 \\
\text { persons }\end{array}$ & X & & X & $\mathrm{X}$ & & & & $\mathrm{X}$ \\
\hline $\begin{array}{l}\text { 2. Sickness } \\
\text { benefits }\end{array}$ & $\begin{array}{c}\text { EUR } \\
11246 \\
\text { million }\end{array}$ & $\begin{array}{l}\text { EUR } 4.21 \\
\text { million }\end{array}$ & $\mathrm{X}$ & $\mathrm{X}$ & & & & & & $\mathrm{X}$ \\
\hline $\begin{array}{l}\text { 3. Support to the } \\
\text { self-employed }\end{array}$ & $\begin{array}{c}\text { EUR } \\
57.18 \\
\text { million / } \\
74 \\
\text { thousand } \\
\text { persons }\end{array}$ & $\begin{array}{c}\text { EUR } \\
29.89 \\
\text { million / } \\
10 \\
\text { thousand } \\
\text { persons }\end{array}$ & $\mathrm{X}$ & X & & $\mathrm{X}$ & & & & $\mathrm{X}$ \\
\hline $\begin{array}{l}\text { 4. Unemployment } \\
\text { benefits }\end{array}$ & $\begin{array}{c}\text { EUR 23.0 } \\
\text { million }\end{array}$ & $\begin{array}{c}\text { EUR } 68.5 \\
\text { million }\end{array}$ & $X$ & X & & & & & & $\mathrm{X}$ \\
\hline $\begin{array}{l}\text { 5. Social } \\
\text { protection of } \\
\text { artists }\end{array}$ & $\begin{array}{l}\text { EUR } 0.58 \\
\text { million }\end{array}$ & $\begin{array}{l}\text { EUR } 0.00 \\
\text { million }\end{array}$ & $\mathrm{X}$ & $\mathrm{X}$ & & & & & & $\mathrm{X}$ \\
\hline \multicolumn{11}{|l|}{$\operatorname{Aim} 3:$} \\
\hline 1. Tax loans & $\begin{array}{c}\text { EUR } \\
37.00 \\
\text { million }\end{array}$ & $\begin{array}{c}\text { EUR } \\
84.79 \\
\text { million }\end{array}$ & & & & & $\mathrm{X}$ & & & \\
\hline $\begin{array}{l}\text { 2. Deferral of tax } \\
\text { arrears }\end{array}$ & $\begin{array}{c}\text { EUR } \\
624.66 \\
\text { million }\end{array}$ & $\begin{array}{c}\text { EUR } \\
134.54 \\
\text { million }\end{array}$ & & & & & $\mathrm{X}$ & & & \\
\hline $\begin{array}{l}\text { 3. INVEGA loans } \\
\text { Subsidising } \\
\text { Agricultural } \\
\text { Credit Guarantee } \\
\text { Fund (ACGF) } \\
\text { loans }\end{array}$ & $\begin{array}{c}\text { EUR } \\
210.0 \\
\text { million } \\
\text { EUR } 8.2 \\
\text { million } \\
\text { EUR } 84.7 \\
\text { million } \\
\end{array}$ & $\begin{array}{l}\text { EUR } \\
190.1 \\
\text { million } \\
\text { EUR 47 } \\
\text { million } \\
\text { EUR 9 } \\
\text { million }\end{array}$ & $\mathrm{X}$ & & & & & $\mathrm{X}$ & $\begin{array}{l}X \\
X\end{array}$ & \\
\hline
\end{tabular}

Government expenditure and loans to non-financial corporations are stationary processes with trend and intercept. All other macroeconomic indicators as well as housing price fluctuations are integrated processes of order one. Thus, their differentiated values are used for further analysis.

Granger causality test shows that government expenditure (GE), unemployment (UN), liquidity ratio, household cash and deposits (CD), and loans to non-financial corporations (LO) Granger cause the housing price. Linear function is the best to describe the relationship between the housing price and the above-mentioned macroeconomic indicators. Meanwhile, the causal relationship between the housing price and subsidies, total wages and social benefits is not observed. The final results of the ARDL model after elimination of multicolinearity and non-significant

Estimates of the ARDL Model

Table 2

\begin{tabular}{|c|c|}
\hline Variables and criteria & Model parameters and values of criteria \\
\hline $\mathrm{C}$ & $-12.5245 * *$ \\
\hline$\Delta \mathrm{UNt}_{\mathrm{t}-2}$ & $-12.7947 * * *$ \\
\hline$\Delta \mathrm{GE}_{\mathrm{t}-1}$ & $0.0365 * * *$ \\
\hline$\Delta \mathrm{LO}_{\mathrm{t}}$ & $0.0390 * * *$ \\
\hline$\Delta \mathrm{CD}_{\mathrm{t}}$ & $0.0682 * * *$ \\
\hline Adjusted $\mathrm{R}^{2}$ & 0.5594 \\
\hline DW & 1.9915 \\
\hline $\mathrm{p}(\mathrm{JB})$ & 0.0000 \\
\hline $\mathrm{p}\left(\chi^{2}\right)$ : Breusch-Pagan-Go & 0.1369 \\
\hline $\mathrm{n}$ & 64 [2004Q3-2020Q2] \\
\hline
\end{tabular}
parameters are presented in Table 2. 
Thus, four macroeconomic indicators (government expenditure, unemployment, household cash and deposits, and loans to non-financial corporations) have a significant impact on the housing price, but at a different moment. If loans to non-financial corporations as well as household cash and deposits rise, the housing price increases the same quarter. Government expenditure also has a positive effect on the housing price, but a more significant impact can be observed after three months. If unemployment rate rises, the housing price significantly decreases after half a year. Although the model and its parameters are significant, the model's precision is not high (adjusted $\mathrm{R}^{2}$ is equal to 0.56 ). The residuals in the model are homoscedastic and not autocorrelated. However, they are not normally distributed likely due to the outliers in the third quarter of 2008 and in the first quarter of 2009, when the housing price fell sharply (Figure 1).

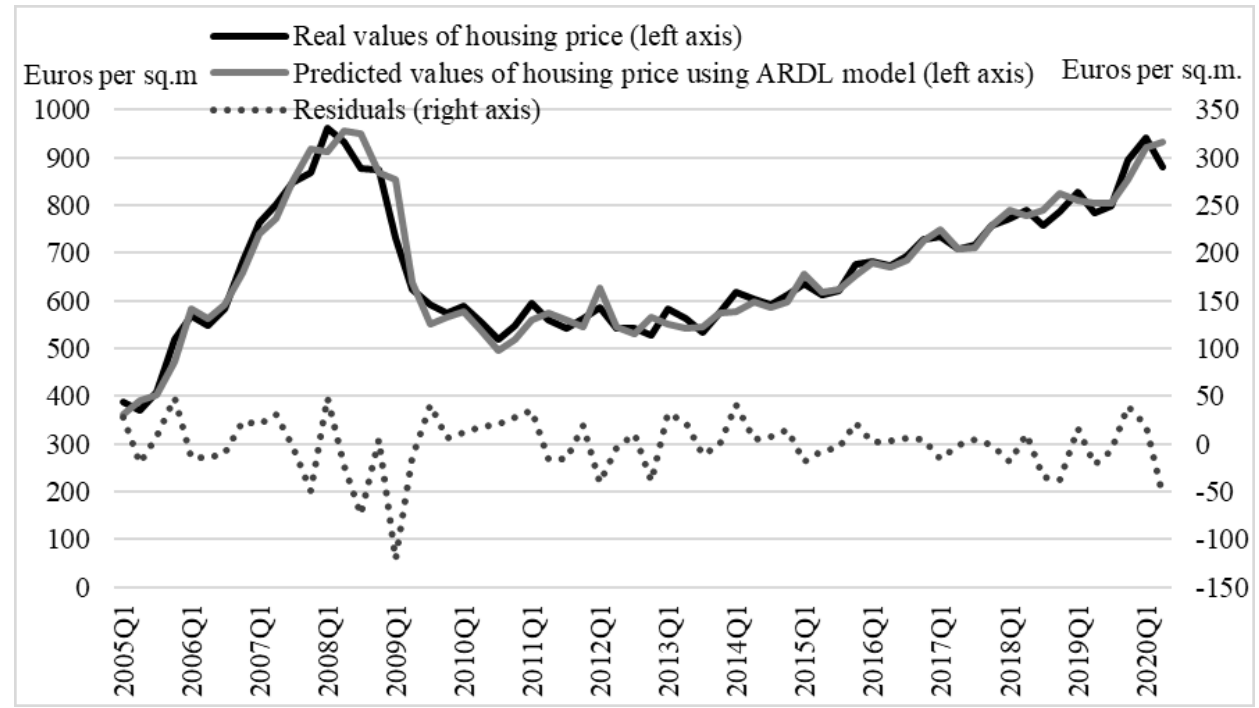

Figure 1. Real and Predicted Values of the Housing Price and the Residuals of the ARDL Model (EUR per sq.m.) 2005Q1 2020Q2 (Source: compiled by the authors based on the data from the State Enterprise Centre of Registers and the authors' estimations)

The estimations show that based on the amount of loans issued to non-financial corporations and household cash and deposits recorded in the second quarter of 2020, the housing price had to grow by 1.2 percent compared to the previous quarter (to EUR 933.84 per sq.m.) (Figure 2). This increase is observed because of the rapid growth of household cash and deposits, which rose by 14.8 percent compared to the same quarter of the previous year and delivered the highest growth rate since mid-2008.

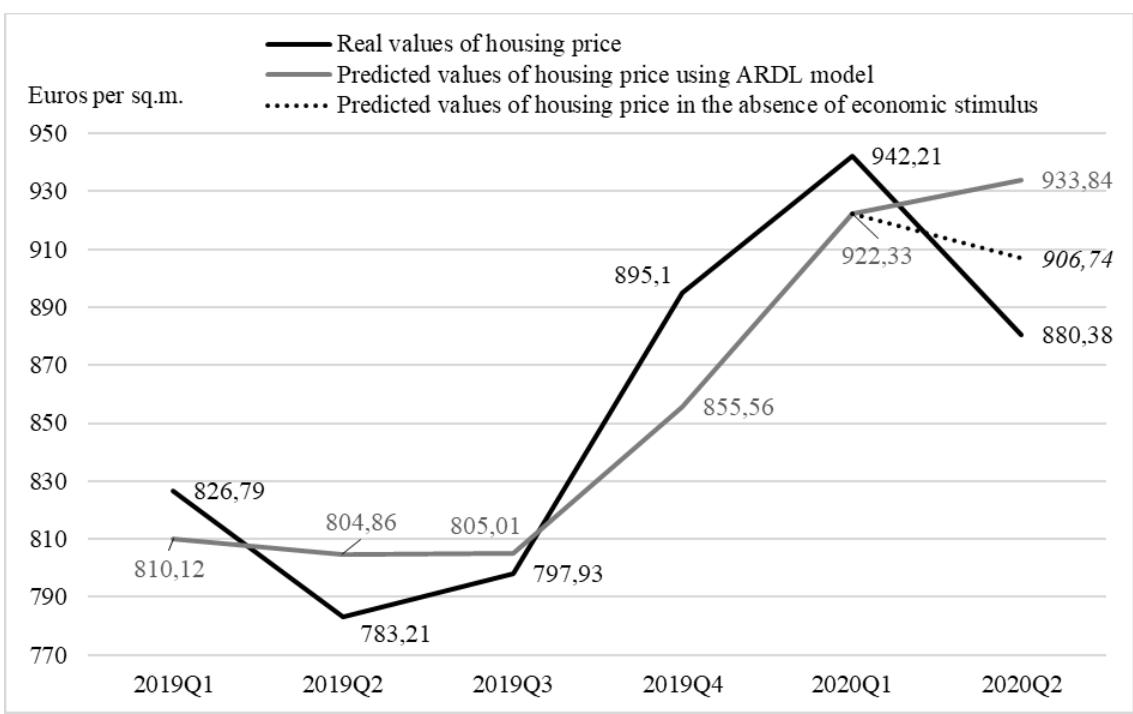

Figure 2. Comparison of the Housing Price: Real Values, Predicted Values based on the ARDL Model and Predicted Values in the Absence of Economic Stimulus Measures (Source: compiled by the authors based on the data from the State Enterprise Centre of Registers and the authors' estimations)

The values of the variables in the ARDL model are adjusted based on the extent of the economic stimulus and the predicted values of the housing price. They indicate the expected values of the housing price if no economic stimulus measures are undertaken. If the funds allocated as the economic stimulus measures are subtracted, the 
reestimated housing price based on the ARDL model is 2.9 percent lower (i.e. EUR 906.74 per sq.m.). It should be noted that only two fluctuating indicators (loans to nonfinancial corporations and household cash and deposits) have an impact on the housing price in the second quarter of 2020. Later the difference in the housing price (determined by the economic stimulus measures compared to the situation when no measures are undertaken) is greater due to the significant effects of the additional two indicators (unemployment rate and government expenditure).

The results of the research approve that maintainance of household cash and deposits as well as lending to enterprises are the measures that let stabilize the RE market in the shortest time under the conditions of an economic shock. A sufficient amount of money allows households to feel safe and resilient to an economic shock. Loans allow corporations to continue their performance and save jobs. These measures form business and household expectations that largely cause the changes in the RE market. All other types of the governmental support are also important, especially if they are aimed at preserving jobs (dealing with unemployment).

\section{Conclusions}

The research revealed that to prevent the RE market and general economic imbalances, the interventional role of a state must be focused on cyclicality, i.e. expectations of the RE market participants should not be unreasonably stimulated during the periods of an economic upswing, but protection against the forced sales of the RE should be ensured during the periods of an economic shock. A set of monetary, fiscal and macroprudential policy measures must be unique for each country with consideration of the level of its development, macroeconomic conditions, structure of the economy and the aim to preserve the stability of the RE market under the conditions of an economic shock.

The econometric analysis revealed that the economic stimulus measures undertaken by the Government of the Republic of Lithuania affected such macroeconomic indicators as government expenditure, unemployment rate, loans to non-financial corporations, and household cash and deposits which, in their turn, have a significant impact on housing prices. The forecast modelling based on the abovementioned indicators revealed that although in the second quarter of 2020, the economic shock caused housing prices to fall by 6.6 percent compared to the previous quarter, they would have fallen by further 2.9 percent in the absence of the economic stimulus measures. The research results indicate that in the current quarter, housing prices are affected only by fluctuations in household cash and deposits, and the volume of loans issued to business corporations, while the other indicators are characterised by a lagged effect. In subsequent periods, housing price fluctuations are likely to be greater due to the cumulative impact of several financial instruments.

Nevertheless, it must be noted that the housing prices projected by the research model deviate from the real prices due to the outliers inherent to the model; thus, the accuracy of the forecast should be treated with caution. In addition, it should not be overlooked that the economic stimulus measures did not prevent the fall in the housing prices which under the conditions of an economic shock dropped by 6.6 percent in the second quarter of 2020 compared to the previous quarter, although the prices are likely to have fallen by almost 3 percent less than in the absence of any economic stimulus measures. The indicators included in the ARDL model, i.e. government expenditure, unemployment, household cash and deposits and loans to non-financial corporations, are not capable of measuring the fluctuations in housing prices in the event of an economic shock. They indicated the further housing price growth, only much more moderate. For these reasons, it is needed to identify the macroeconomic indicators which could better explain housing price fluctuations and which could be employed as a basis for assessing the impact of economic stimulus measures on stabilising the RE market under the conditions of an economic shock. The analysis of more indicators may also reveal new economic stimulus measures which may be advisable to stabilize the real estate market. This is an idea of our future research.

Summarising, it can be stated that the economic stimulus measures approved by the Lithuanian government only partially contribute to stabilising the RE market. The measures approved by the Lithuanian goverment for achieving the second and third aims are the most beneficial in terms of maintaining the RE market stability because they focus on protecting population's income and corporate liquidity. The benefits provided by other measures are less significant or will be observed in the long run. The prices in some RE market segments showed a quick response to the economic shock, and in order to prevent this response from turning into a decline of the entire RE market, it is neccesary to undertake such economic stimulus measures that would have the quickest possible effect.

\section{Acknowledgement}

This paper was prepared based on the project funded by the Research Council of Lithuania (LMTLT) within the "Projects for decisions on the consequences of COVID-19", agreement No S-COV-20-9.

\section{References}

Allam, Z. (2020). Chapter 7 - Vital COVID-19 Economic Stimulus Packages Pose a Challenge for Long-Term Environmental Sustainability. Editor(s): Zaheer Allam. Surveying the Covid-19 Pandemic and its Implications. Urban Health, Data Technology and Political Economy. Elsevier, 2020, 97-105. https://doi.org/10.1016/B978-0-12-8243138.00007-3.

Amedee-Manesme, C. O., Barthelemy, F., \& Prigent, J. L. (2015). Real estate investment: Market volatility and optimal holding period under risk aversion. Economic Modelling, 58, 543-555. https://doi.org/10.1016/j.econmod.2015.10.033 
Anghel, I., \& Hristea, A. M. (2015). Some Considerations Regarding the International Real Estate Market-Present and Future Predictions. Procedia Economics and Finance, 32, 1442-1452. https://doi.org/10.1016/S2212-5671(15)01520-8.

Akhtaruzzaman, M., Boubaker, S., \& Sensoy, A. (2020). Financial contagion during COVID-19 crisis. Finance Research Letters, 101604, In Press. https://doi.org/10.1016/j.frl.2020.101604.

Azbainis, V. (2013). Nekilnojamojo turto rinkos ciklu valdymo vertinimas ir modeliavimas. Daktaro disertacija, Vilnius: MRU.

Bank of Lithuania. (2020a). Finansinio stabilumo apzvalga.

Bank of Lithuania. (2020b). Statistics. Available from internet: https://www.lb.lt/lt/statistikos-temines-lenteles-1\#group1030 .

Belhadia, A., Kamble, S. S., Jabbourc, C. J. C., Gunasekaran, A., Ndubisi, N. O., \& Venkatesh, M. (2020). Manufacturing and service supply chain resilience to the COVID-19 outbreak: Lessons learned from the automobile and airline industries. Technological Forecasting and Social Change, 120447, In Press. https://doi.org/10.1016/j.techfore.20 20.120447.

Bloch, B. (1997). Volatility in the residential housing market: an international perspective. Property Management, 15(1), 12-24. https://doi.org/10.1108/02637479710162168

Bruneckiene, J., Pekarskiene, I., Palekiene, O., \& Simanaviciene, Z. (2019). An assessment of socio-economic systems' resilience to economic shocks: The case of Lithuanian regions. Sustainability,11(3), 566. https://doi.org/10.3390/su 11030566

Carriere-Swallow, Y., \& Cespedes, L. F. (2013). The impact of uncertainty shocks in emerging economies. Journal of International Economics, 90(2), 316-325. https://doi.org/10.1016/j.jinteco.2013.03.003.

Cassim, Z., Handjiski, B., Schubert, J., \& Zouaoui, Y. (2020). The $\$ 10$ trillion rescue: How governments can deliver impact. McKinsey \& Company. Available from internet: https://www.mckinsey.com/industries/public-and-social-sector/ourinsights/the-10-trillion-dollar-rescue-how-governments-can-deliver-impact.

Choi, S. Y. (2020). Industry volatility and economic uncertainty due to the COVID-19 pandemic: Evidence from wavelet coherence analysis. Finance Research Letters. https://doi.org/10.1016/j.frl.2020.101783.

Cocconcelli, L., \& Medda, F. R. (2013). Boom and bust in the Estonian real estate market and the role of land tax as a buffer. Land Use Policy, 30(1), 392-400. https://doi.org/10.1016/j.landusepol.2012.04.007.

Goodell, J. W., \& Huynh, T. L. D. (2020). Did Congress trade ahead? Considering the reaction of US industries to COVID19. Finance Research Letters, 36, 101578. https://doi.org/10.1016/j.frl.2020.101578.

Government of the Republic of Lithuania. Korona Stop: Relevant Information about Coronavirus (COVID-19). Available from internet: https://koronastop.lrv.lt/lt/pagalba-verslui

Haas, R., \& Greef, I. (2000). Housing Prices, Bank Lending, and Monetary Policy. De Nederlandsche Bank Research Series Supervision Paper, 31.

Hossain, M. (2020). The effect of the Covid-19 on sharing economy activities. Journal of Cleaner Production, In Press, 124782. https://doi.org/10.1016/j.jclepro.2020.124782.

Johnson, L. D., \& Neave, E. H. (2008). The subprime mortgage market: familiar lessons in a new context. Management Research News, 31(1), 12-26. https://doi.org/10.1108/01409170810845921

Karpavicius, H. (2012). Classification and interpretation of macroeconomic exogenous shocks-the case of Lithuania. Socialiniai tyrimai, 2, 89-97.

Laing, T. (2020). The economic impact of the coronavirus 2019 (COVID-2019): implications for the mining industry. The Extractive Industries and Society, 7(2), 580-582. https://doi.org/10.1016/j.exis.2020.04.003.

Leduc, S., \& Liu, Z. (2020). The uncertainty channel of the coronavirus. FRBSF Economic Letter, 2020 (07).

Lu, X., \& Dong, Z. (2016). Dynamic Correlations between Real Estate Prices and International Speculative Capital Flows: An Empirical Study Based on DCC-MGARCH Method. Procedia Computer Science, 91, 422-431. http://doi.org/10.10 16/j.procs.2016.07.114

McDonald, C. (2015). When is macroprudential policy effective? BIS Working Papers, No. 496.

Matkenaite, S., Ramanauskas, T., \& Reichenbachas, T. (2016). Paskolos ir užstato vertes santykio ribojimo Lietuvoje ekonominiai aspektai. Teminių straipsniu serija. Vilnius: Lietuvos bankas.

Mazur, M., Dang, M., \& Vega, M. (2020). COVID-19 and the March 2020 stock market crash. Evidence from S\&P1500. Finance Research Letters, In Press. https://doi.org/10.1016/j.frl.2020.101690.

Minsky, H. P. (1992). The Financial Instability Hypothesis. The Jerome Levy Economics Institute Working Paper No. 74, Available at SSRN: https://ssrn.com/abstract=161024 or http://dx.doi.org/10.2139/ssrn.161024.

Mirza, N., Naqvi, B., Rahat, B., \& Rizvi, S. K. A. (2020). Price reaction, volatility timing and funds' performance during Covid-19. Finance Research Letters, 36, 101657. https://doi.org/10.1016/j.frl.2020.101657.

Paavonen, T. A. (2010). A New World Economic Order. Helsinkis: FIIA. 
Palekiene, O., Simanaviciene, Z., \& Bruneckiene, J. (2015). The application of resilience concept in the regional development context. Procedia-Social and Behavioral Sciences, 213, 179-184. https://doi.org/10.1016/j.sbspro. 2015.11.423

Sharif, A., Aloui, C., \& Yarovaya, L. (2020). COVID-19 pandemic, oil prices, stock market, geopolitical risk and policy uncertainty nexus in the us economy: fresh evidence from the wavelet-based approach. International Review of Financial Analysis, 70, 101496. https://doi.org/10.1016/j.irfa.2020.101496.

Shehzad, K., Xiaoxing, L., \& Kazouz, H. (2020). COVID-19s disasters are perilous than global financial crisis: a rumor or fact? Finance Research Letters, 36, 101669. https://doi.org/10.1016/j.frl.2020.101669.

Shim, I., \& Shin, H. S. (2014). Comparative Assessment of Macroprudential Policies. Bank for International Settlements.

Sodra. (2020). Atviri įmonių duomenys. Available from internet: https://atvira.sodra.lt/imones/rinkiniai/index.html

State Enterprise Centre of Registers. (2020). Open data and statistics. Available from internet: https://www.registrucentras.lt/ atviri_duomenys/

Statistics Lithuania (2020). Official Statistics Portal. Available from internet: https://osp.stat.gov.lt/statistiniu-rodikliuanalize\#/

Sidlauskaite-Riazanova, B., Seputiene, J. (2008). BVP ir infliacijos kitimo skirtumu ir bendros pinigu politikos optimalumo sarysis. Ekonomika ir vadyba: aktualijos ir perspektyvos, 4, 367-373.

Tanrivermis, H. (2020). Possible impacts of COVID-19 outbreak on real estate sector and possible changes to adopt: A situation analysis and general assessment on Turkish perspective. Journal of Urban Management, 9, $263-269$. https://doi.org/10.1016/j.jum.2020.08.005

Yarovaya, L., Matkovskyy, R., \& Jalan, A. (2020). The effects of a'black swan'event (covid-19) on herding behavior in cryptocurrency markets: evidence from cryptocurrency USD, EUR, JPY and KRW markets. EUR, JPY and KRW markets (April 27, 2020). Available at SSRN: https://ssrn.com/abstract=3586511 or http://dx.doi.org/10. 2139/ssrn.3586511

Zhang, D., Hu, M., \& Ji, Q. (2020). Financial markets under the global pandemic of COVID-19. Finance Research Letters, 36, 101528. https://doi.org/10.1016/j.frl.2020.101528.

Zhang, L., \& Zoli, E. (2014). Leaning Against the Wind: Macroprudential Policy in Asia. IMF Working Paper 14/22. https://doi.org/10.5089/9781475572476.001

\section{Authors' Biographies}

Vaida Pilinkienè Dr. is Professor and Director of the Economics Study Programmes Committee at the School of Economics and Business, Kaunas University of Technology, Lithuania. Her research interests focus on modelling and forecasting economic processes, industry competitiveness, real estate market, sharing economy. ORCID iD 0000-0002$8373-2471$

Alina Stundžienė Dr. is Associate Professor in Economics at School of Economics and Business, Kaunas University of Technology, Lithuania. Her research interests include economic modelling, prediction, labour economics, real estate market, energy, etc. ORCID iD 0000-0001-6812-8471

Andrius Grybauskas Dr. is a Researcher at ERA Chair team, IN4ACT at the School of Economics and Business in Kaunas University of Technology. He received undergraduate degree in economics and finance, graduate degree in International Trade and Economics and a Ph.D. in Economics at Kaunas University of Technology. Andrius research themes mostly revolves around the real estate market and its stability, housing bubbles, econometrics, Big Data, REITs, machine learning, forecasting, Industry 4.0 and artificial intelligence.

Evaldas Stankevičius is a doctor of science in the field of social sciences (economics), a researcher of the research group "Sustainable Economy" of Kaunas University of Technology, School of Economics and Business. Evaldas has experience in various research and study projects. The main areas of scientific interest are state budget tax revenues; research on the impact of economic growth on the social and fiscal spheres of sustainable development.

The article has been reviewed.

Received in November 2020; accepted in October 2021.

This article is an Open Access article distributed under the terms and conditions of the Creative Commons Attribution 4.0 (CC BY 4.0) License (http://creativecommons.org/licenses/by/4.0/). 